\title{
Filsafat Etika Tasawuf Syaikh 'Abdul Qadir al-Jailani: Kajian Etika Salik dalam Kitab Ghunyat li Thalibi Thariq al-Haqq
}

\author{
Aly Mashar ${ }^{1}$, Nailal Muna $^{2}$ \\ ${ }^{1}$ IAIN Surakarta, ${ }^{2}$ IAI-Tribakti Kediri \\ Ialymashariainskt@email.com, ${ }^{2}$ nmuna72@email.com
}

\begin{abstract}
This brief paper wishes to examine the ethical concept of Sufism Shaykh Abdul Qadir al-Jailani in the book Ghunyat li Thalibi Thariq al-Haqq, especially the ethics of Sufism of a salik found in the last part of the book. This paper is classified as library research with analysis using the perspective of ethical philosophy. Sufism values remain in the corridors of the Qur'an and Sunnah, the soul is clean from impulse, always bound and happy with Allah, maintain harmony, emphasize respect and an attitude of compassion, and not be the cause of others hurt. If observed in terms of the source of truth that always measures with the source of texts, both the Qur'an, the sunnah of the prophet, friends, tabi'ain and the saints, then it can be said that the ethics of Sufism Shaykh Abdul Qadir al-Jailani belong to theological ethics. However, if seen from the emphasis on the priority of people rather than the salik, then it falls into the category of ethical altruism.
\end{abstract}

Key Word: Abdul Qadir, Ethics, Sufism

\begin{abstract}
Abstrak
Tulisan singkat ini ingin mengkaji konsep etika tasawuf Syaikh Abdul Qadir alJailani dalam kitab Ghunyat li Thalibi Thariq al-Haqq, khususnya etika tasawuf seorang salik yang terdapat pada bagian terakhir dari kitab tersebut. Tulisan ini tergolong penelitian library research dengan analisis menggunakan perspektif filsafat etika. nilai-nilai tasawuf tetap dalam koridor al-Qur'an dan sunnah, jiwa bersih dari dorongan nafsu, selalu terikat dan ridha dengan Allah Swt, menjaga keharmonisan, menekankan penghormatan dan sikap kasih sayang, dan tidak menjadi penyebab orang lain sakit hati. Jika diamati dari segi sumber kebenarannya yang selalu mengukur dengan sumber nash, baik al-Qur'an, sunnah nabi, sahabat, tabi'ain dan para wali, maka bisa dikatakan bahwa etika tasawuf Syaikh Abdul Qadir al-Jailani masuk pada etika teologis. Namun, jika dilihat dari penekanannya pada pengutamaan orang dari pada diri sang salik, maka masuk dalam kategori etika altruisme.
\end{abstract}

Kata Kunci: Abdul Qadir, Etika, Tasawuf

\section{Pendahuluan}

Manusia sejak dilahirkan ke dunia selalu bersentuhan dengan nilai atau moral. Menurut Frans Magnis Suseno, manusia lahir dan hidup di tengah-tengah taman moral di mana dia berada. Singkatnya, manusia selalu dan tidak bisa lepas dari sentuhan nilai atau moral di mana ia dilahirkan dan hidup. Secara 
garis besar, ilmu yang membahas tentang nilai disebut etika. Pertanyaan utamanya adalah apa yang seharusnya dilakukan manusia?, apa ukuran yang digunakan untuk menilai yang 'baik' dan yang 'buruk'?, dan bagaimana cara melakukan yang 'baik' dan meninggalkan yang 'buruk'?

Dalam konteks Agama Islam, cabang ajaran yang membahas terkait nilai atau 'baikburuk' adalah akhlak, lebih khususnya adalah tasawuf. Di antara ulama tasawuf terkemuka dalam catatan sejarah Islam, salah satunya adalah Syaikh Abdul Qadir al-Jailani dan tarekatnya, tarekat Qadiriyah. Konsep etika tasawuf tokoh yang disebut pula sebagai sulthan al-auliya' tersebut di antaranya ialah ia tuangkan dalam salah satu karyanya, yaitu kitab Ghunyat li Thalibi Thariq al-Haqq.

Tulisan singkat ini ingin mengkaji konsep etika tasawuf Syaikh Abdul Qadir alJailani dalam kitab Ghunyat, khususnya etika tasawuf seorang salik yang terdapat pada bagian terakhir dari kitab tersebut. Persoalan dalam kajian ini, akan penulis kaji dan analisis menggunakan perspektif filsafat etika yang terpusat pada tiga pertanyaan filsafat etika sebagaimana di atas.

\section{Metode Penelitian}

Tulisan ini menggunakan metode kepustakaan yang termasuk ke dalam penelitian kualitatif. Sumber datanya adalah karya al-Jailani yang kemudian dianalisis dengan metode content analysis.

\section{Syaikh 'Abdul Qadir al-Jailani: Sekilas Biografi dan Karya}

Nama lengkap Syaikh 'Abdul Qadir adalah Syaikh Abu Muhammad Muhyiddin 'Abdul Qadir al-Jailani. Ia dilahirkan di Jilan, di balik Thabaristan, sebelah selatan laut Kaspia Iran, pada tahun 1078 M./ 471 H. ${ }^{1}$ Ia lahir dari keluarga ulama, sederhana dan keturunan dari Fatimah binti Rasulullah. Dari jalur ayahnya, ia memiliki jalur nasab sampai ke Hasan bin Ali, sedangkan dari jalur ibu memiliki jalur nasab sampai ke Husen bin Ali. Rentetan nasab dari jalur ayah adalah Syaikh 'Abdul Qadir al-Jailani bin Musa bin 'Abdullah bin Janki Dausat bin 'Abdullah al-Jili bin Yahya az- Zahid bin Muhammad bin Dawud bin Musa bin Abdullah bin Musa al-Juni bin Abdullah alMahdhi bin Hasan al-Mutsni bin Ali bin Abi Thalib. Sedangkan dari ibu adalah Syaikh 'Abdul Qadir al-Jailani bin Fatimah binti Abdullah as-Shumi'i bin Jamaluddin bin Muhammad bin Mahmud bin Abdullah bin Kamaluddin Isa bin Muhammad al-Jawad bin Ali ar-Ridha bin Musa al-Kadzim bin Ja'far ash-Shadiq bin Muhammad al-Baqir 
bin Ali Zainal Abidin bin Husen bin Ali bin Abi Thalib. ${ }^{2}$

Pendidikan awal Syaikh 'Abdul Qadir berada di bawah asuhan langsung kakeknya yang merupakan sorang sufi dan ulama terkemuka, Syaikh Abdullah asShauma'i. Selain itu, ia juga belajar kepada ulama-ulama lain di Jilan yang juga masih tergolong kerabatnya. Sejak kecil, ia dikenal sebagai anak yang saleh, rajin ibadah, dan zuhud. Selain itu, ia juga dikenal sebagai anak yang haus akan ilmu, baik ilmu ushul maupun furu'. Oleh karena itu, ia kemudian memutuskan untuk pergi ke Baghdad, pusat peradaban dan pengetahuan dunia ketika itu. $^{3}$

Sebagaimana pengakuannya sendiri, pada usia 18 tahun, tepatnya tahun $488 \mathrm{H}$, ia pergi ke Baghdad untuk melanjutkan studinya. Waktu itu bersamaan dengan meninggalnya seorang ulama besar Baghdad, Syaikh Abu Muhammad Rizqullah at- Tamimi, dan pada masa pemerintahan Khalifah al-Mustadhir Billah Abul Abbas Ahmad bin al-Muqtadi bi Amrillah Abul Qasim Abdullah al-Abbasiy. ${ }^{4}$ Pada waktu itu juga bersamaan dengan keputusan Hujjatul Islam Abu Hamid al-Ghazali memutuskan untuk melepaskan posisinya di Nidhamiyah dan memilih untuk uzlah. ${ }^{5}$

Di kota seribu satu malam ini, Syaikh 'Abdul Qadir belajar tentang al-Qur'an, Fikih, hadith, kalam, sastra, tasawuf dan ilmu-ilmu agama lainnya. Dalam keilmuan al-Qur'an, qira'at, dan tafsir, Syaikh 'Abdul Qadir berguru kepada Abu al- Wafa ibn 'Uqail al-Hanbali dan Abu al-Khaththab Mahfuzh al-Kaludzani. Kepada kedua ulama tersebut, Syaikh 'Abdul Qadir juga belajar tentang fikih Hanbali. Selain itu, dalam fikih Hanbali, ia juga belajar kepada al-Qadhi Abu Sa'd al-Mubarak ibn Ali al-Mukharrami dan Abu al-Hasan Muhammad ibn al-Qadhi Abu Ya'la al-Fira' al- Hanbali. ${ }^{6}$ Dalam ilmu dan riwayat hadith, Syaikh 'Abdul Qadir berguru kepada Abu Ghalib alBaqilani, Ja'far as-Siraj al-Baghdadi, Ahmad at-Tammar, Muhammad ibn Maimun anNursi, Abul Qasim ar-Razaz, Abu Thalib alYusufi, dan Ahmad al-Banna. Yang disebut terakhir tidak lain adalah sepupu Abul Barakat as-Siqthi. Dengan banyaknya guru dalam hadith ini, maka tidak heran jika ia juga dikenal sebagai ahli hadith. Karyakaryanya banyak memuat hadith Nabi SAW. ${ }^{7}$ Kemudian dalam keilmuan tasawuf,

6 Abdul Razzaq al-Kailani, , Syaikh Abdul Qadir Jailani: Guru Para Pencari Tuhan, 103-4.

${ }^{7}$ Sutomo Abu Nashr, Syekh Abdul Qadir Jaelani \& Ilmu Fiqih, 12.
2,Abdul Qadir Al Jailani, 1:19-20.

${ }^{3}$ Djanky Dausat, Samudera Kehidupan Syekh Abdul Qodir Al-Jailani, 20-21.

${ }^{4}$ Djanky Dausat, 21.

₹ 5 Shalih Ahmad al-Syami, Syekh Abdul Qadir Al-

N Jailani: Kisah Hidup Sultan Para Wali Dan Rampai Pesan Yang Menghidupkan Hati, 16. 
bidang ilmu yang kemudian menjadikannya ulama terkemuka hingga sekarang, Syaikh 'Abdul Qadir berguru kepada Abu Muhammad Ja'far ibn Ahmad al- Siraj, alQadhi Abu Sa'd al-Mukharrami, dan Syaikh Hammad ibn Muslim al-Dibas. ${ }^{8}$

Setelah usai menuntut ilmu kepada beberapa ulama dan sufi terkemuka di Baghdad, Syaikh Abdul Qadir melakukan pengembaraan guna mengasah kepribadian, jiwa, dan lebih mengenal masyarakat, khususnya di Baghdad. Dalam masa pengembaraan ini, ia pernah tinggal beberapa tahun di sebuah menara yang tidak dipakai di Baghdad. Sebagai orang asing tak dikenal, ia lama menempati menara itu, akhirnya menara itu dikenal dengan nama Burj al-Gharib (menara orang asing). Selain itu, Syaikh Abdul Qadir juga pernah tinggal di reruntuhan bangunan di wilayah alMada'in dan Istana Kisra kurang lebih selama 3 tahun.

Terdapat perbedaan pendapat mengenai lama waktu pengembaraan Syaikh Abdul Qadir. Ada pendapat yang menyatakan selama 14 tahun dan ada pula yang menyatakan selama 25 tahun. Pendapat terakhir sebagaimana yang diutarakan oleh al- Sya'rani dalam karyanya, at-Thabaqat alKubra. Kemudian, setelah dirasa cukup dan tujuan pengembaraannya tercapai, ia

8 Abdul Razzaq al-Kailani, , Syaikh Abdul Qadir Jailani: Guru Para Pencari Tuhan, 103.

${ }^{9}$ Abdul Razzaq al-Kailani, 110. kembali ke kota Baghdad dan membuka halaqah. Oleh masyarakat dan ulama sekitar, ketika itu ia dikenal sebagai seorang ulama ahli fikih Hanbali, bukan sebagai seorang sufi. Hal ini berubah setelah ia bertemu serta berguru kepada Syaikh Hammad ibn Muslim al-Dibas dan Syaikh Abu Sa'd al- Mubarak al-Mukharrami. Dari guru yang disebut terakhir inilah Syaikh Abdul Qadir mendapatkan khirqah tarekatnya. ${ }^{9}$ Silsilah khirqahnya adalah sebagai berikut: Syaikh 'Abdul Qadir dari al-Qadhi Abu Sa'd alMubarak al-Mukharrami, dari Abul Hasan Ali bin Muhammad al-Qaurasyi, dari Abul Faraj at-Tharsusi, dari Abul Fadhal Wahid at- Tamimi, dari Abu Bakar as-Syibli, dari Imam Abul Qasim al-Junaidi, dari Imam Sari as-Saqathi, dari Makruf al-Karkhi, dari Imam Dawud at-Thai, dari Imam Hubaib alAjmi, dari Imam Hasan al-Bashri, dari Ali bin Abi Thalib, dari Nabi Muhammad Saw. Selain dari Syaikh Abu Sa'd al-Mubarak, Syaikh Abdul Qadir juga mendapatkan khirqah tarekat dari beberapa guru sufi lainnya, di antaranya ialah dari Syaikh Abu Ya'kub Yusuf bin Ayub bin Yusuf alHamdani. ${ }^{10}$

Syaikh Abu Sa'd al-Mukharrami, selain memberikan khirqah tarekat kepada Syaikh Abdul Qadir, juga memintanya untuk melanjutkan kepengelolaan madrasahnya.

${ }^{10}$ Djanky Dausat, Samudera Kehidupan Syekh Abdul Qodir Al-Jailani, 18-19. 
Madrasah ini dirintis oleh Syaikh Abu Sa'd dan berada di daerah Bab al-Azj, Baghdad. ${ }^{11}$

Setelah pengelolaan berpindah kepada Syaikh Abdul Qadir, madrasah tersebut semakin besar dan banyak murid berdatangan. Madrasah ini kemudian dikenal dengan nama Madrasah Qadiriyah. Banyak murid madrasah tersebut yang kemudian menjadi ulama besar, di antaranya adalah: 'Abdurrazaq ibn Abdul Qadir al-Jailani, Musa Ibn 'Abdul Qadir al-Jailani, 'Abdul Wahhab ibn 'Abdul Qadir al-Jailani, Abu As'ad as-Sam'ani, Abdul Ghani al-Maqdisi, Ibnu Qudamah al-Muwaffaq al-Maqdisi, Ali al-Ya'qubi, Ibnu al-Wasthani, Akmal ibn Mas'ud al-Hasyimi, Nashr ibn Fityan alHanbali, dan masih banyak lagi. ${ }^{12}$

Syaikh Abdul Qadir menikah dalam usia yang tidak muda lagi, yaitu 51 tahun. Kendatipun demikian, ia memiliki banyak putra. Disebutkan bahwa ia memiliki 20 putra dan 20 puteri. Putranya yang terkenal adalah 'Abdurrazaq ibn Abdul Qadir alJailani, Musa Ibn 'Abdul Qadir al-Jailani, dan 'Abdul Wahhab ibn 'Abdul Qadir alJailani. ${ }^{13}$

Syaikh Abdul Qadir memiliki beberapa karya, yang mayoritas adalah hasil

11 Shalih Ahmad al-Syami, Syekh Abdul Qadir AlJailani: Kisah Hidup Sultan Para Wali Dan Rampai Pesan Yang Menghidupkan Hati, 28.

12 Muhammed Fadil al-Jailani al-Hasani, Biografi Syaikh Abdul Qadir Al-Jailani (Depok: Keira Publishing), pp. 8-10 dari kumpulan ceramah-ceramah dan nasehat-nasehatnya. Karya yang disepakati para pakar sebagai karya Syaikh Abdul Qadir hanya ada tiga, yaitu: al-Ghunyat, alFath al- Rabbani, dan Futuh al-Ghayb. ${ }^{14}$ Sedangkan, karya lain yang dinisbatkan kepadanya dan masih menjadi perdebatan mengenai kesahihannya antara lain adalah: Ighatsatul 'Arifin, Aurad al-Jailani, Adab alSuluk wa al-Tawasul, Tuhfat al-Muttaqin wa Sabil al-'Arifin, al-Risalah al-Ghoutsiyah, al-Fuyudhat al-Rabbaniyah, Sirrul al-Asror, Tafsir al-Jailani, dan masih banyak lagi hingga lebih dari 40 buah karya. ${ }^{15}$.

Tokoh yang dikenal sebagai Sulthan al-Auliya' ini wafat pada tahun $1166 \mathrm{M}$, atau bertepatan dengan tanggal 10 Rabiul Tsani tahun $561 \mathrm{H}$. Jenasahnya disalati oleh para santri dan keluarganya, yang dipimpin oleh putranya yang bernama Abdul Wahab bin Abdul Qadir al-Jailani. Kemudian ia dimakamkan di pemakaman Madrasah Qadiriyah, Baghdad. ${ }^{16}$

\section{Kitab Ghunyat li Thalibi Thariq al-Haqq:} Sekilas Isi

Judul lengkap kitab adalah alGhunyat li Thalibi al-Haq 'Azza wa Jalla.

\footnotetext{
${ }^{14}$ Shalih Ahmad al-Syami, Syekh Abdul Qadir AlJailani: Kisah Hidup Sultan Para Wali Dan Rampai Pesan Yang Menghidupkan Hati, 79-80.

15 Muhammed Fadil al-Jailani al-Hasani, Biografi Syekh Abdul Qadir Al-Jailani, 180.

${ }_{16}$ 'Abdul Qadir Al Jailani, Al-Ghunyah Lithalibi Thariq al-Haq, 1991, 1:1.
} 
Kitab ini, menurut 'Isham Faris, adalah satu dari tiga kitab utama karya Syaikh 'Abdul Qadir al-Jailani. Dua kitabnya yang lain adalah al-Fath al-Rabbani wa al-Faidl alRahmani dan Futuh al-Ghayb. Lanjut Faris, kitab yang disebut terakhir, Futuh alGhuyub, telah disyarahi oleh Syaikhul Islam Ibnu Taimiyah menjadi beberapa ratus halaman, dan mengumpulkannya dalam satu jilid kitabnya, al-Fatawa. Tepatnya adalah pada jilid yang ke-sepuluh. Bagi Ibnu Taimiyah, Syaikh 'Abdul Qadir al-Jailani merupakan tokoh istimewa di samping Imam Ahmad Ibnu Hanbal. Pernyataan atau fatwa dari kedua tokoh tersebut banyak menghiasi kitab-kitab karyanya. Khusus untuk pernyataan Syaikh 'Abdul Qadir al-Jailani, selain mengumpulkannya dalam jilid ke sepuluh kitab al-Fatawa, Ibnu Taimiyah juga menyusun dua karya lain yang khusus memuat pernyataan-pernyataan tokoh yang terkadang ia laqobi dengan Qutbul 'Arifin itu. Kedua karya tersebut adalah Kitab Iqtidla' al-Shirat al-Mustaqim dan Minhaj al- Sunnah al-Nubuwah. ${ }^{17}$

Hal di atas menunjukkan bahwa Syaikh 'Abdul Qadir al-Jailani merupakan tokoh luar biasa dan mampu menerobos sekat. Ibnu Taimiyah yang notabene dikenal sebagai tokoh yang amat kuat memegang dhahiru an-Nash dan amat kritis terhadap tasawuf atau tarekat, ia memuji serta memosisikan tokoh sufi dan pendiri Tarekat Qadiriyah tersebut pada posisi yang amat mulia, yakni setara dengan tokoh idolanya, Imam Ahmad Ibnu Hanbal. Realita penerimaan Ibnu Taimiyah terhadapnya ini juga bisa dipahami dengan pemahaman lain, yaitu sebagai bukti bahwa bentuk tasawuf Syaikh 'Abdul Qadir al-Jailani adalah bentuk tasawuf yang sesuai dengan ajaran Rasulullah dan Salaf al-Shalih, minimal dalam perspektif Ibnu Taimiyah. Artinya, tasawuf Syaikh 'Abdul Qadir al-Jailani adalah tasawuf yang memerhatikan dan mengimbangkan antara sisi dhahiriyah maupun sisi bathiniyah, sisi syari'ah maupun sisi haqiqah, dan sisi dunyawiyah maupun sisi ukhrawiyah, yang tidak lain adalah ajaran Islam itu sendiri dan yang dipraktikkan oleh Rasulullah, para sahabat, dan para salaf al-shalih.

Menurut penjelasan dalam pendahuluan kitab, sebagaimana lazimnya para ulama klasik lain, Syaikh 'Abdul Qadir al-Jailani menyusun kitab al-Ghunyat li Thalibi al-Haq atas dasar permintaan dari para sahabat dan murid-muridnya. Setelah mengetahui kesungguhan niat dari para sahabat dan murid-muridnya tersebut, kemudian ia memutuskan untuk memenuhinya. Supaya tujuan dari penyusunan kitab tercapai, yakni memberi bekal yang cukup pada jalan yang haq seperti 
arti dari judul kitab, Syaikh 'Abdul Qadir alJailani menyusun kitab Ghunyat dengan model mukhtashar, ringkas. ${ }^{18}$

Kendatipun dikatakan oleh penyusunnya sebagai mukhtashar, namun bukan berarti bahwa jumlah halaman kitab Ghunyat sedikit. Bahkan, untuk ukuran orang sekarang, kitab Ghunyat tergolong kitab yang amat tebal dan banyak halaman. Menurut cetakan Dar al-Kotob al-Ilmiyah, Libanon, jumlah halaman kitab Ghunyat mencapai 704 halaman, sedangkan menurut cetakan Dar al-Jail, Beirut, berjumlah 742 halaman ditambah dengan kata pengantar dari pentahqiq-nya, Isham Faris. Karena tergolong tebal, baik Dar al-Kotob alIlmiyah maupun Dar al-Jail mencetaknya menjadi 2 jilid. Namun, jika dilihat dari banyaknya hal yang dicakupnya, jumlah halaman yang mencapai ratusan tersebut bukanlah jumlah yang banyak. Artinya, penyebutan kitab Ghunyat sebagai kitab mukhtashar adalah benar adanya.

Terkait isi kitab Ghunyat, dalam muqaddimah kitab Syaikh 'Abdul Qadir alJailani menulis sebagai berikut: ${ }^{19}$

$$
\text { فلما رأيت صدق رغبته في معرفة الاداب الشرعية من الفرائض و والاركان }
$$

$$
\begin{aligned}
& \text { القرأن والألفاظ النبوية في بحالس نذكر, } \\
& \text { ومعرفة أخلاق الصالحين نشير لها في أثناء الكتاب }
\end{aligned}
$$

Dalam kutipan di atas, Syaikh 'Abdul Qadir al-Jailani menjelaskan bahwa kitab Ghunyat berisikan tentang empat hal, yaitu: fikih, akidah, amalan yang sesuai dengan al Qur'an hadits, dan akhlak.

Sedangkan menurut penjelasan Sutomo Abu Nashr, isi kitab Ghunyat bisa dikelompokkan menjadi lima, yaitu: 1) tentang fikih, 2) akidah, 3) al-majalis yang berisikan tentang faidah ayat-ayat serta keutamaan bulan dan hari, 4) fadhail ala'mal (amal-amal yang utama), dan 5) tentang tasawuf. ${ }^{20}$ Hal senada, namun lebih detail, sebagaimana dijelaskan oleh pentahqiq kitab, Isham Faris. Menurutnya, isi kitab Ghunyat bisa dikelompokkan sebagaiman berikut:

1) Fikih, yang meliputi fardhu dan rukunnya salat, zakat, puasa dan haji.

2) Adab, yang meliputi adab salam, meminta izin, makan, minum, adab ketika di kamar mandi, berpakaian, tidur, ketika bepergian, birul walidain, adab berdo'a, amar ma'ruf nahi munkar, dan adab nikah.

3) Akidah, yang meliputi pengetahuan tentang sang pencipta, keyakinan bahwa al- Qur'an adalah kalamullah dan berupa huruf yang memahamkan, serta

${ }^{20}$ Sutomo Abu Nashr, Syekh Abdul Qadir Jaelani \& Ilmu Fiqih, 24. 
penjelasan tentang firqah yang sesat.

4) Nasehat-nasehat al-Qur'an, yang meliputi beberapa majelis, yaitu: a) majelis tentang makna dan faidah isti'adzah; b) majelis tentang keutamaan basmalah, c) majelis tentang syarat dan cara bertaubat; d) majelis tentang takwa, cara ikhlas dengan kezaliman para hamba, sifat surga dan neraka serta balasan Allah terhadap ahlinya; e) majelis tentang keutamaan Bulan Rajab, Sya'ban, Ramadhan, dan Lailatul Qadar; f) majelis tentang keutamaan ayam al'asyr, hari 'Arafah, 'Idul Adha; dan g) majelis tentang keutamaan dan kesunahan Hari Jum'at.

5) Tasawuf, yang meliputi adab para salik, adab berteman dan bergaul, mujahadah, tawakal, syukur, sabar, ridha, jujur, dan perilaku para ahli mujahadah dan muhasabah dari ulul 'azmi. ${ }^{21}$

Terlepas dari adanya perbedaan jumlah dan jenis pengelompokan, jika diamati sebenarnya mereka memiliki maksud yang sama dan bisa ditarik benang merah. Dari ketiga penjelasan di atas, bisa ditarik pemahaman bahwa kitab Ghunyat secara garis besar berisikan tentang fikih, akidah, fadla'il a'mal, dan akhlak atau tasawuf. Jika dilihat dari isi kajiannya ini, dan juga dari segi coraknya yang fikih-sufistik, maka kitab
Ghunyat memiliki kesamaan dengan kitab Ihya' 'Ulumuddin karya al-Ghazali. Mungkin atas dasar inilah sebagian pakar menyatakan bahwa Syaikh 'Abdul Qadir al- Jailani mendapat pengaruh dari al-Ghazali, setidaknya dalam penyusunan kitab Ghunyat ini.

Perlu diketengahkan di sini bahwa, sebagai seorang yang juga ahli dalam hadith, bahkan ulama setingkat al-Dzahabi dan Ibnu Rajab juga menuliskan hadith melalui sanad Syaikh Abdul Qadir, kitab Ghunyat banyak dihiasi kutipan hadith. Menurut penjelasan Nashr, dalam kitab tersebut terdapat lebih dari seribu hadith. 110 hadith di antaranya bersanadkan kepada dua guru hadithnya, Syaikh Ibnu Mubarok as-Siqthi dan Ibnu Hasan al-Banna.

\section{Etika Seorang Salik dalam Kitab Ghunyat}

\section{li Thalibi Thariq al-Haqq}

Pada sub-bab ini, penulis akan mendeskripsikan etika tasawuf praktis yang harus dilakukan oleh seorang salik dalam Tarekat Qadiriyah. Dalam kitab Ghunyat, oleh Syaikh Abdul Qadir penjelasan tersebut disusun dalam bagian tersendiri di bagian kitab paling belakang. Guna mempermudah, penulis akan mengelompokkan menjadi tiga kelompok dan menguraikannya masingmasing sebagaimana anak sub-bab berikut:

1. Etika Salik sebelum Suluk 
Sebelum melakukan suluk atau memasuki tarekat, seorang salik harus memiliki enam etika. Enam etika ini oleh Syaikh Abdul Qadir disebut sebagai shifat al-murid. Keenam sifat tersebut adalah sebagai berikut: pertama, harus memiliki akidah yang benar. Benar di sini maksudnya adalah akidah ahlusunnah, yakni akidah yang diikuti oleh mereka yang memegang teguh sunnah nabi, sunnah para sahabat, tabi'in, dan para wali ${ }^{22}$

$$
\begin{aligned}
& \text { الاعتقاد الصحيح الذى هو الاساس ,فيكون على عقيدة السلف } \\
& \text { الصالح اهل السنة القديمة سنة الانبياء والمرسلين ,و الصحابه } \\
& \text { و التابعين ,و الاولياء و الصديقين } 23
\end{aligned}
$$

Kedua, harus berpegang dengan alQur'an dan sunnah dalam semua aktifitasnya, serta mengamalkan semua yang ajaran di dalamnya, baik perintah maupun larangan, baik ushul maupun furu'.

فعلبه بالتمسك بالكتاب والسنة والعمل بها امرا وغيا اصلا وغيا فيجعله جناحيه يطير بكما في الطريق الواصل الى الله عز 24 وجل وفيا فيجل

Ketiga, harus ikhlash kepada Allah. Ia harus ikhlas dalam menjalankan semua perintah-Nya. Artinya, salik harus mengabaikan semua halang rintang yang menggoda tercapainya tujuan utamanya, yaitu

${ }^{22}$ Sutomo Abu Nashr, Syekh Abdul Qadir Jaelani \& Ilmu Fiqih, 17.

23 'Abdul Qadir Al Jailani, Al-Ghunyah Lithalibi Tharig al-Haq, n.d., II:227.
Allah SWT. Baik itu berupa hinaan maupun kemuliaan yang diberikan oleh makhluk.

$$
\text { قدما يجب في طريقه اليه ولا يضعها الا باله ما لم يصل الله } 25
$$

Selain itu, ia juga harus rela dan ridha dengan apa yang dikehendaki atau diberikan oleh-Nya untuknya dalam segala kondisi. Misalnya hidup dalam kehinaan, kelaparan, dan serba kekurangan. Kendatipun dalam situasi seperti itu, ia harus mendahulukan orang lain dan mengakhirkan dirinya dalam mendapatkan kemuliaan dan rezeki.

$$
\text { وينبغ له ان يرضى بالذل الدائم وحرمان النصيب والجوع }
$$

الدائم والخمول وذم الناس له وتقديم اضرابه واشكاله واقرانه

$$
\text { عليه في الاكرام والعطاء } 26
$$

Keempat, harus meninggalkan tempattempat yang penuh kekurangan, dan menjauhi orang-orang yang berbuat kebatilan, yang memusuhi amal dan kewajiban, serta yang hanya mengklaim dalam keislaman dan keimanan padahal hakikatnya sebaliknya.

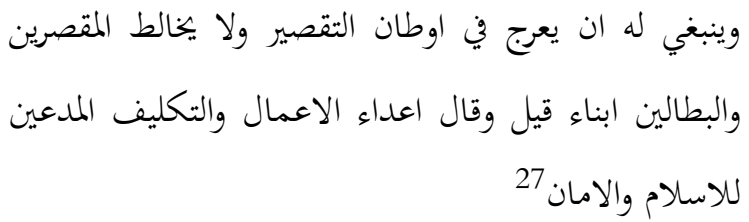

Kelima, harus meninggalkan sifat kikir dalam segala hal, terutama masalah harta 
benda. Di dalam hatinya, ia harus lain adalah: selalu menganggap benar apa memantapkan bahwa Allah tidak akan yang diajarkan dan dilakukan sang guru, mengangkat seorang wali dari orang yang kendatipun secara dhahiriyah nampak salah. kikir.

Seandainyapun terpaksa hendak

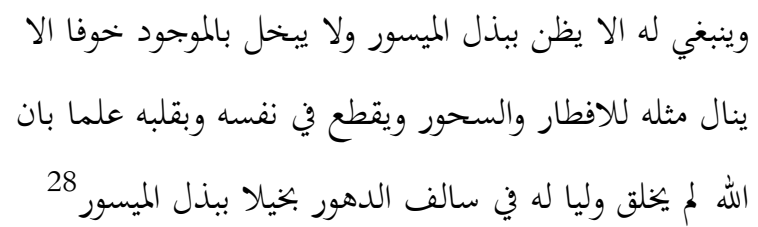

Keenam, tidak boleh menuntut kepada Allah, kecuali dalam hal ampunan dari dosadosa masa lalu, pemeliharaan diri-Nya dari dosa-dosa akan datang, dan taufik dari-Nya untuk mengantarkan kepada-Nya.

وينبغي له الا ينتظر من الله مطلوبا سوى المغفرة لما سلف من

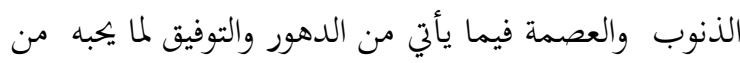
الطاعات ويوصله اليه من القربات 29

\section{Etika Salik dalam Suluk}

Seorang salik, atau dalam bahasa Syaikh Abdul Qadir adalah al-faqir, ketika dalam proses suluk atau bertarekat, harus memenuhi etika sebagaimana berikut:

a. Etika terhadap guru.

Terhadap gurunya, salik harus meyakini bahwa tidak ada seorang pun di daerah itu yang lebih utama dibandingkan dirinya. Dengan begitu, salik akan mendapatkan manfaat dari gurunya. ${ }^{30}$ Selain itu, salik harus taat dan menghormatinya, baik secara dhahir maupun bathin. Perincian adab dari taat dan menghormatinya antara mengingatkannya, harus dengan cara isyarat atau cara-cara lain yang tidak menghilangkan muru'ah sang guru; tidak boleh menunjukkan rasa ketaksetujuan kepada sang guru; jika ia menyalahi guru, seperti halnya ia marah kepada sang guru atau meninggalkan perintah atau melakukan dosa, hendaknya ia segera meminta maaf kepada sang guru dan bertaubat kepada Allah SWT; tidak berbicara kepada sang guru kecuali dalam hal-hal yang penting saja; ketika muncul permasalahan di hadapan guru, hendaknya ia diam kendatipun ia mengetahui jawaban atau solusinya; mendengarkan dengan seksama ketika sang guru sedang menjelaskan, bergerakpun harus dihindari; tidak menunjukkan kelebihan yang diberikan oleh Allah kepadanya di hadapan sang guru, kecuali jika sang guru menyuruhnya; dan sikap-sikap lain yang intinya adalah perwujudan dari ketaatan dan penghormatan kepada sang guru. ${ }^{31}$

b. Etika bergaul

Dalam etika bergaul ini Syaikh Abdul Qadir membaginya menjadi empat, yaitu: bergaul dengan sesama salik, dengan orang asing, dengan orang kaya, dan dengan 
orang miskin. Pertama, bergaul dengan sesama salik. Inti dari etika bergaul sesama salik adalah hormat, memberikan bantuan, menjaga kondisi hatinya, dan mendahulukannya dibanding dirinya dalam segala hal. Di antara bentuk sikap praktisnya dari etika ini antara lain: menampakkan kesepakatan dengannya; menjauhi perselisihan dengannya; tidak menekannya; tidak membeda-bedakannya; jika di antara mereka berselisih hendaknya ia menerima ucapan dhahiriyah-nya; terus menggaulinya kendatipun mereka menunjukkan kebencian terhadap dirinya; menujukkan sikap kasih sayang kepadanya; menunjukkan wajah yang berseri-seri; ketika diberi sesuatu harus segera menunjukkan kegembiraan; dan lain sebagainya. $^{32}$

Kedua, dengan orang asing. Etika bergaul dengan mereka adalah menjaga rahasia mereka, memandang mereka dengan penuh rasa hormat dan kasih sayang, tidak boleh menunjukkan hukum-hukum tarekat kepada mereka; tidak merasa tinggi hati; menganggap mereka atau tarekat mereka sama posisinya dengan tarekatnya; dan yang senada lainnya. ${ }^{33}$

Ketiga, dengan orang kaya. Di antara etikanya adalah membesarkan diri di hadapan mereka; tidak mengikat diri mereka dan yang mereka miliki ke dalam hati; tidak tamak kepada mereka; tidak menjual agama kepada mereka; tetap merasa diri lebih rendah dari semua makhluk; mengarahkan mereka untuk menyayangi orang miskin; dan lain sebagainya yang intinya adalah tetap menjaga diri dari ketergantungan kepada selain Allah SWT dan mengarahkan mereka ke jalan yang diridhai-Nya. ${ }^{34}$

Keempat, dengan orang miskin (faqir). Di antara etika kepada mereka adalah: hormat dan mendahulukan kebutuhan mereka; tetap merasa lebih rendah dibanding mereka; tidak memperlihatkan kelebihan atau keutamaan kepada mereka; mengarahkan mereka untuk lepas dari ketergantungan dengan orang kaya; bersabar dengan cerita atau keluh kesah mereka; tidak mengulur bantuan; ketika memberi hutang hendaknya hanya diuangkapkan dari sisi dhahiriyah saja dan secara bathin membebaskannya; memberikan rasa lapang kepada mereka; dan lain sebagainya. ${ }^{35}$

\section{c. Etika dengan keluarga}

Seorang salik harus menjaga etika yang baik dengan keluarga dan anaknya. Di antara etika tersebut adalah: memberikan nafkah yang baik dan dengan cara yang baik sesuai kemampuan; tidak menyimpan sesuatu dari mereka; ketika punya sesuatu yang cukup untuk hari itu, hendaknya 
dihabiskan ketika itu; tidak makan kecuali bersama dengan mereka; memosisikan diri sebagai pelayan mereka dan meniatkannya sebagai ketaatan kepada Allah; tidak memaksa mereka untuk menuruti kemauan dirinya; mengedepankan kebutuhan mereka dibanding dirinya; tidak memaksa mereka mengikuti kondisi dan kekuatan dirinya; jika ada tamu hendaknya memberikan makanan yang sama di antara mereka; bersabar dengan sikap mereka; menjaga silaturrahmi dengan mereka; mengajarkan ilmu agama dan akhlak kepada mereka; membimbing mereka dlam hal mengamalkan agama; dan lain sebagainya. ${ }^{36}$

Selain etika-etika di atas, seorang salik juga harus menjaga etika-etika berikut: pertama, etika atas kefakirannya. Jika ia dalam keadaan fakir, maka ia hendaknya menikmati kefakirannya sebagaimana orang kaya menikmati kekayaannya. Ia juga harus mempertahankan kefakirannya tersebut sebagaimana orang kaya mempertahankan kekayaannya. Ia tidak boleh berdo'a kepada Allah untuk menghilangkan kefakirannya. Ia harus ridha terhadap kefakirannya tersebut dan menganggapnya sebagai bentuk ketaatan kepada Allah SWT. Ia pun tidak boleh khawatir terhadap masa depannya. Kefakirannya tersebut tidak boleh menjadi alasan untuk tidak sungguh-sungguh dalam menjalankan ibadah. Kendatipun demikian, bukan berarti bahwa ia meninggalkan usaha untuk mencari rejeki. ${ }^{37}$

Kedua, sang salik tidak boleh meminta kepada makhluk, ketika ia masih memiliki sesuatu yang cukup. Ketika miliknya tidak cukup, maka ia harus menghabiskan terlebih dahulu baru kemudian meminta bantuan kepada orang lain. Permintaan bantuan inipun, harus hanya cukup untuk keperluannya. Itupun, ia harus memosisikan bahwa pada hakikatnya yang memberi bantuan tersebut adalah Allah. Begitupun jika permintaan bantuan itu ditolak, ia harus memandang bahwa yang menolak adalah Allah. Dengan begitu dia harus menerima dengan lapang dada bahwa itu adalah ketentuan-Nya, dan membuang jauh-jauh rasa marah. Jika ia menerima bantuan, hendaknya ia bersyukur kepada Allah. ${ }^{38}$

Ketiga, etika ketika makan. Di antara etikanya adalah ia hendaknya tidak makan sesuatu yang buruk dan dalam keadaan lupa. Artinya, ketika makan ia harus selalu mengingat Allah. Ketika dalam majelis, ia tidak boleh mendahului makan sebelum orang lain, duduk di tempat yang tidak ditujukan untuknya, mengangkat makanan orang miskin ketika mereka masih sedang makan atau menginginkannya, menyisakan

38 'Abdul Qadir Al Jailani, II:294. 
makanan maupun minuman ketika ia diberi, memikirkan makanan yang tidak ada di hadapannya dan lain sebagainya. Intinya ia hanya makan sesuai kebutuhannya saja dan senantiasa menjaga hati tetap ingat dan bersyukur kepada Allah. ${ }^{39}$

Keempat, etika ketika bepergian. Inti etika ketika salik bepergian adalan membuang segala akhlak jelek darinya dan menghiasi dirinya dengan akhlak yang baik selama perjalanan. Hal ini dimaksudkan supaya ia tidak dikuasai hawa nafsu dan tetap mengharap ridha Allah. Ketika ia memiliki keluarga dan mereka dalam situasi menghadapi bahaya, hendaknya ia membatalkan bepergiannya. Bepergiannya tidak boleh menjadi alasan untuk mengurangi wirid atau melakukan rukhshah. Selama dalam perjalananya ia harus menjaga pergaulan dengan baik orang yang ditemuinya, dan menghindari pertentangan dengan mereka. Selain keempat kelompok etika sebagaimana diuraikan di atas, masih terdapat etika-etika lain yang hendaknya dilakukan oleh sang salik. ${ }^{40}$ Namun intinya adalah tetap berada dalam koridor al-Qur'an dan sunnah, jiwanya bersih dari dorongan nafsu, selalu terikat dan ridha dengan Allah, memosisikan dirinya lebih rendah dibanding yang lain, mengakhirkan dirinya dibanding yang lain dalam memberikan bantuan, penghormatan dan sikap kasih sayang, dan tidak menjadi penyebab orang lain sakit hati.

3. Etika Salik terhadap Sang Maha tujuan Suluk

Kitab Syaikh Abdul Qadir menjelaskan etika yang harus dimiliki oleh seorang salik terhadap Allah. Etika tersebut adalah: tawakal, syukur, sabar, ridha, dan $a l$ sidqu. Pertama, tawakal. Menurut Syaikh Abdul Qadir, hakikat tawakal adalah menyerahkan segala urusan kepada Allah dan melepaskan diri dari gemerlapnya penghargaan. Lanjutnya, tawakal memiliki tiga tingkatan, yaitu: tawakal, penyerahan, dan penyandaran. Maksudnya adalah salik merasa tenang dengan janji Allah (tawakal), lalu hal ini dibarengi dengan penyerahan diri secara penuh kesadaran kepada Allah, dan kemudian diikuti dengan penyandaran kepada hukum-hukum Allah yang tidak lain adalah sikap rela terhadap semua ketentuanNya.

Kedua, syukur. Menurut Syaikh Abdul Qadir, hakikat syukur adalah mengakui nikmat yang diberikan kepadanya oleh Allah dengan penuh sikap rendah diri. Menurutnya, syukur terbagi menjadi beberapa bagian, yaitu: syukur lisan, syukur badan, dan syukur hati. Syukur lisan adalah pengakuan akan nikmat diikuti dengan ketundukan; syukur badan adalah dengan melakukan penyembahan kepada Allah; dan 
syukur hati adalah senantiasa merasa berada dalam pengawasan Allah disertai dengan meninggalkan semua hal yang diharamkan oleh-Nya.

Ketiga, sabar. Menurut Syaikh Abdul Qadir, yang disandarkan pada pendapat alKhawwash RA. Sabar adalah teguh bersama Allah dengan menjalankan hukum-hukum al-Qur'an dan sunnah, serta menerima penderitaan atau cobaan dari-Nya dengan lapang dada dan senang hati. Menurutnya, sabar terbagi menjadi tiga bagian, yaitu: sabar karena Allah, sabar bersama Allah, dan sabar atas Allah. Sabar karena Allah adalah mengerjakan segala perintah dan menjauhi segala larangan-Nya; sabar bersama Allah adalah bersabar terhadap segala ketentuan dan perbuatan-Nya; dan sabar atas Allah adalah bersabar atas segala yang dijanjikanNya.

Keempat, ridha. Menurut Syaikh Abdul Qadir ridha adalah menghilangkan pilihan diri dalam hatinya. Mereka tidak memilih sesuatu di antara sesuatu yang diinginkan dirinya, dan sesuatu yang diinginkan Allah untuk dirinya, serta tidak meminta dan mencari suatu hukum sebelum hukum itu turun.

Kelima, as-Sidqu. Menurut Syaikh Abdul Qadir, as-sidqu adalah orang yang berulang kali membenarkan. Imbasnya adalah 'benar' menjadi karakteristik dirinya, dan akhirnya kebenaran menjadi lebih dominan pada dirinya. Dalam memaknai kata 'benar', Syaikh Abdul Qadir memaknainya sebagai seimbangnya antara lahir dan batin. Artinya, orang yang benar adalah orang yang benar secara perkataannya, perbuatannya, dan dalam segala kondisinya. ${ }^{41}$

\section{Kesimpulan}

Dari uraian di atas maka bisa ditarik kesimpulan bahwa etika tasawuf seorang salik menurut Syaikh Abdul Qadir al-Jailani, tepatnya pada kitab Ghunyat, adalah memusat pada nilai-nilai tetap dalam koridor al-Qur'an dan sunnah, jiwanya bersih dari dorongan nafsu, selalu terikat dan ridha dengan Allah, memosisikan dirinya lebih rendah dibanding yang lain, mengakhirkan dirinya dibanding yang lain dalam memberikan bantuan, menjaga keharmonisan, menekankan penghormatan dan sikap kasih sayang, dan tidak menjadi penyebab orang lain sakit hati.

Nilai-nilai tersebut mewujud dalam etika praktis baik sebelum salik masuk tarekat, ketika dalam tarekat, etika bergaul dalam kehidupannya, dan etika kepada Allah. Untuk menanamkan nilai-nilai tersebut tidak lain adalah dengan cara mujahadah melalui media tarekat. Tarekat di sini maksudnya adalah Tarekat Qadiriyah. Jika diamati dari segi sumber kebenarannya yang selalu 
mengukur dengan sumber nash, baik al-

Qur'an, sunnah nabi, sahabat, tabi' in dan para wali, maka bisa dikatakan bahwa etika tasawuf Syaikh Abdul Qadir al-Jailani masuk pada etika teologis. Namun, jika dilihat dari penekanannya pada pengutamaan orang dari pada diri sang salik, maka masuk dalam kategori etika altruisme.

\section{Daftar Pustaka}

Dausat, Djanky. Samudera Kehidupan Syekh Abdul Qodir Al-Jailani. Yogyakarta: Penerbit Mihrab, n.d.

Hasani, Muhammed Fadil al-Jailani al. Biografi Syekh Abdul Qadir Al-Jailani. Depok: Keira Publishing, n.d.

Jailani, 'Abdul Qadir Al. Al-Ghunyah Lithalibi Thariq al-Haq. Vol. 1. Beirut: Dar al-Jail, 1991.

_. Al-Ghunyah Lithalibi Thariq al-Haq. Vol. II. Beirut: Dar al-Jail, n.d.

Kailani, Abdul Razzaq al-. Syaikh Abdul Qadir Jailani: Guru Para Pencari Tuhan. Bandung: Mizania, 2009.

Nashr, Sutomo Abu. Syekh Abdul Qadir Jaelani \& Ilmu Fikih. Jakarta: Rumah Fikih Publishing, 2018.

Syami, Shalih Ahmad al-. Syekh Abdul Qadir Al-Jailani: Kisah Hidup Sultan Para Wali Dan Rampai Pesan Yang Menghidupkan Hati. Jakarta: Zaman, 2012. 